\title{
Temperature-dependent changes in proteolytic activities and protein composition in the psychrotrophic bacterium Arthrobacter globiformis $\mathbf{S}_{1} 55$
}

\author{
Patrick Potier, ${ }^{1} \uparrow$ Pascal Drevet, ${ }^{1}$ Anne-Monique Gounot ${ }^{1}$ and Alan R. Hipkiss ${ }^{2 *}$ \\ ${ }^{1}$ Laboratoire de Microbiologie Physiologique et Appliquée, URA CNRS 697, Université Claude-Bernard-Lyon 1, \\ 43 boulevard du 11 Novembre 1918, 69622 Villeurbanne Cedex, France \\ ${ }^{2}$ Department of Biochemistry, King's College London, Strand, London WC2R $2 L S, U K$
}

(Received 4 August 1989; revised 16 October 1989; accepted 6 November 1989)

\begin{abstract}
Proteolytic activities, active against casein and insulin are present in cell-free extracts of the psychrotrophic bacterium Arthrobacter globiformis $S_{1} 55$. These activities were compared (i) following growth of the bacterium at different temperatures $\left(10,20\right.$ and $32{ }^{\circ} \mathrm{C}$ ) and (ii) after a temperature shift from 10 to $32{ }^{\circ} \mathrm{C}$. Both activities (measured at $20^{\circ} \mathrm{C}$ ) were greater in cells grown at $32{ }^{\circ} \mathrm{C}$ and after a temperature shift. Chloramphenicol prevented the increases in activities. The proteolysis of casein was stimulated by ATP; the stimulation was greater following a temperature shift. In addition, proteolysis of casein (measured at $20^{\circ} \mathrm{C}$ ) was activated by pre-incubation at temperatures between 45 and $60^{\circ} \mathrm{C}$; the proportion of proteolytic activity activated by such treatment also increased with growth temperature. Comparison by two-dimensional electrophoresis of the polypeptides synthesized at 10 and $32^{\circ} \mathrm{C}$ suggests that $A$. globiformis $S_{1} 55$ produces proteins specific to both temperatures (13 species were either exclusive to or present in increased amounts during growth at $10{ }^{\circ} \mathrm{C}$, while at least 21 polypeptides were preferentially synthesized at $32{ }^{\circ} \mathrm{C}$ ). A temperature shift from 10 to $32{ }^{\circ} \mathrm{C}$ promoted the synthesis of at least 16 polypeptides, many with $M_{\mathrm{r}}$ values similar to those of heat shock proteins synthesized at higher temperatures in mesophiles. A temperature up-shift of $A$. globiformis $S_{1} 55$ from 10 to $20{ }^{\circ} \mathrm{C}$ did not provoke the synthesis of new proteins; heat shock proteins were produced only at $28{ }^{\circ} \mathrm{C}$ and higher. The similarity in kinetics of the appearance of heat shock proteins and the increase in proteolytic activities suggest that in $\mathrm{A} . \mathrm{globiformis}$ $S_{1} 55$ some heat shock proteins might also possess protein catabolic function.
\end{abstract}

\section{Introduction}

According to their ability to grow at high, intermediate or low temperatures, micro-organisms have been divided into three broad categories: thermophiles, mesophiles and psychrophiles respectively. The last category has been further subdivided into psychrophiles sensu stricto, which have optimal growth temperatures below $16^{\circ} \mathrm{C}$ and an upper temperature limit of $20^{\circ} \mathrm{C}$, and psychrotrophs, which are able to divide at $0{ }^{\circ} \mathrm{C}$ or below and grow optimally at temperatures around $20-25^{\circ} \mathrm{C}$ (Morita, 1975). In their natural habitat, psychrotrophic microorganisms are frequently submitted to large and rapid temperature changes and they can develop over a wide temperature range. This ability must be accompanied by adaptative changes in response to alterations of a large number of physical and chemical parameters, including

† Present address: Unité de Microbiologie, Station de Recherches sur la Viande, INRA de Theix, 63122 Ceyrat, France.

Abbreviation: IEF, isoelectric focusing. solubility, reaction kinetics, membrane fluidity and protein conformation. Therefore, the biochemical effects following large temperature changes are likely to be complex, involving a number of interacting phenomena. For example, high and low temperatures may effect structural and functional changes in proteins to modify biological behaviour by altering rates of enzyme activities, which may have important consequences for the integration of biochemical pathways; denaturation events could unfold proteins or cause subunit dissociation. The conformational stability of proteins results from a complex balance of individual forces (hydrogenbonding, electrostatic or hydrophobic interactions) which vary in different ways with temperature. Therefore, all proteins are stable only within a limited temperature range. Intracellular protein catabolism is an interesting example because not only do changes in temperature affect the rate of protein breakdown for kinetic reasons, but the susceptibility of the substrate to proteolytic attack is also determined by its conforma- 
tional state. Of course, extremes of temperatures may inactivate the intracellular proteases or their inhibitors. Indeed a general response to supra-optimal temperatures (sometimes only a few degrees above 'optimum') is the synthesis of heat shock or stress proteins (Craig, 1985; Neidhardt et al., 1984; Yamamori et al., 1978). Proteins of altered conformation (aberrant proteins) can also induce the synthesis of stress proteins (Anathan $e t$ al., 1986; Goff \& Goldberg, 1985; Kelly \& Schlesinger, 1978; Munro \& Pelham, 1985). In Escherichia coli, mutations in some heat shock genes (dnaK, dnaJ, grpE, groES, groEL, lon and rpoH) result in defective in vivo catabolism of puromycyl peptides and of a nonsense fragment of $\beta$-galactosidase (Straus et al., 1988). Conversely, over-expression of these genes results in enhanced rates of proteolysis. Straus et al. (1988) suggest that at least one general function of heat shock proteins is to contribute to the ability of the cells to degrade abnormal peptides.

McCallum et al. (1986) reported that the synthesis of heat shock proteins is induced at relatively low temperatures in a psychrophilic and a psychrotrophic bacterium. Arthrobacter globiformis $\mathrm{S}_{1} 55$ is a psychrotrophic bacterium capable of growth between $-5{ }^{\circ} \mathrm{C}$ and $+32^{\circ} \mathrm{C}$ (Gounot, 1976). This organism was isolated from a Scandinavian arctic glacial region where surface temperature varied considerably. Our previous studies have shown that in vivo proteolysis and in vitro degradation of protein fragments correlate with growth temperature: cells grown at the highest permissible temperature showed the greatest in vivo and in vitro proteolytic activities (Potier et al., 1985, 1987a). Qualitative differences in degradative activity towards protein fragments were also detected in cells grown at 10,20 and $32^{\circ} \mathrm{C}$. Partial characterization of the proteolytic activities using insulin and casein as substrates revealed the presence of proteolytic enzymes with differences in metal-ion requirements, $\mathrm{pH}$ optima, ATP stimulation and heat lability (Potier et al., 1987b,c). The higher rates of protein degradation observed when $A$. globiformis $S_{1} 55$ cells are cultured above their optimal growth temperature could be due to direct effects of temperature on some key protease(s) or on some controlling element(s), and/or to the induction of the synthesis of new enzymes or activators. In this communication, we report our studies on the comparison of the protein pattern and intracellular proteolytic activities present in this bacterium when grown at different temperatures and following temperature changes. The data show that temperature shifts from $10^{\circ} \mathrm{C}$ to supra-optimal growth temperatures result in rapid increases in the rate of both insulin and casein degradation, together with the synthesis of heat shock proteins.

\section{Methods}

Bacterial strain and growth conditions. Arthrobacter globiformis $\mathrm{S}_{1} 55$ was grown aerobically at 10,20 or $32^{\circ} \mathrm{C}$ in a synthetic medium to midexponential phase $\left(\mathrm{OD}_{570} 0.3-0.5\right)$ as previously described (Potier et al., 1985). The generation times at $10^{\circ} \mathrm{C}$ and $20^{\circ} \mathrm{C}$ were $19 \mathrm{~h}$ and $4 \mathrm{~h}$ $40 \mathrm{~min}$ respectively. At $32^{\circ} \mathrm{C}$, growth rate was apparently exponential during the first $7 \mathrm{~h}$, with a generation time of $3 \mathrm{~h} 20 \mathrm{~min}$. The length of bacteria increased progressively with time: after $7 \mathrm{~h}$ at this temperature, cells formed filaments and there was an increase in the apparent generation time to $7 \mathrm{~h} 50 \mathrm{~min}$ (Potier et al., 1985).

Preparation of cell-free extracts. Cells in exponential growth $(500 \mathrm{ml})$ at 10,20 or $32{ }^{\circ} \mathrm{C}$ were harvested by centrifugation at $10000 \mathrm{~g}$ for $10 \mathrm{~min}$ and the pellets were washed twice with fresh medium. Cells were broken by ultrasonic treatment either in buffer $\mathrm{C}(50 \mathrm{~mm}$ Tris/ $\mathrm{HCl}, \mathrm{pH} 8,10 \mathrm{~mm}-\mathrm{CaCl}_{2}, 10 \mathrm{~mm}-\mathrm{MgCl}_{2}, 0.5 \mathrm{~mm}-\mathrm{DTT}$ ) or in buffer I (50 mM-Tris/HCl, pH 6.5, $10 \mathrm{~mm}-\mathrm{CaCl}_{2}, 0.5 \mathrm{~mm}-\mathrm{DTT}$ ) as previously described (Potier et al., 1987b). Unbroken cells were removed by centrifugation at $12000 \mathrm{~g}$ for $10 \mathrm{~min}$ and the supernatants were used immediately to test proteolytic activities.

Extracts of heat shocked cells were obtained by transfering $25 \mathrm{ml}$ of bacteria growing exponentially at $10^{\circ} \mathrm{C}$ into prewarmed $500 \mathrm{ml}$ flasks and incubating at $20,25,28,30$ or $32^{\circ} \mathrm{C}$. With shaking at 100 r.p.m., the $25 \mathrm{ml}$ cultures took less than $3 \mathrm{~min}$ to reach the higher temperatures. Lysozyme $\left(2 \mathrm{mg} \mathrm{ml}^{-1}\right)$ was added to the temperatureshifted cells $10 \mathrm{~min}$ before harvesting. After centrifugation $(12000 \mathrm{~g}$ for $1 \mathrm{~min}$ ) cells were resuspended in $1 \mathrm{ml}$ of either buffer $\mathrm{C}$ or buffer $\mathrm{I}$ containing $400 \mu \mathrm{g}$ chloramphenicol. Cell walls were immediately disrupted by sonication (Braun Labsonic; $60 \mathrm{~W}$ ) for three periods of $2 \mathrm{~min}$ with cooling in an ice-bath. After centrifugation at $12000 \mathrm{~g}$ for $10 \mathrm{~min}$, the supernatants were used immediately to test protein degradation.

Preparation of radiolabelled substrates. Insulin and $\alpha$-casein (Sigma) were methylated with $\left[{ }^{3} \mathrm{H}\right]$ formaldehyde $\left[\mathrm{NEN} ; 75 \mathrm{mCi} \mathrm{mmol}^{-1}\right.$ (2.78 GBq mmol $^{-1}$ )] using the method of Rice \& Means (1970). The specific activity of the various preparations was approximately $2 \times 10^{6}$ c.p.m. (mg protein) $)^{-1}$.

Determination of protein degradation. The degradation of $\left[{ }^{3} \mathrm{H}\right]$ casein was assayed in $A$. globiformis $\mathrm{S}_{1} 55$ cell-free extracts prepared in buffer $\mathrm{C}$, and that of $\left[{ }^{3} \mathrm{H}\right]$ insulin in buffer $\mathrm{I}$. In vitro protein degradation was estimated by measuring the conversion of TCA-precipitable radioactivity into TCA-soluble radioactivity. Extracts $(40 \mu 1)$ containing an equal quantity of DNA $\left(0 \cdot 3 \mathrm{mg} \mathrm{ml}^{-1}\right)$ were mixed with $140 \mu \mathrm{l}$ of either buffer $C$ or buffer $I$, and incubated at the indicated temperatures in presence of $20 \mu \mathrm{l}$ of the appropriate substrates. Unless otherwise indicated, degradation of $\left[{ }^{3} \mathrm{H}\right]$ casein and $\left[{ }^{3} \mathrm{H}\right]$ insulin was stopped after incubation with the cell-free extracts for $50 \mathrm{~min}$ and $10 \mathrm{~min}$, respectively (Potier $e$ t al., 1987b), by mixing samples $(50 \mu \mathrm{l})$ with $5 \mu \mathrm{l}$ $5 \%(\mathrm{w} / \mathrm{v}) \mathrm{BSA}$ as a carrier and diluting into $50 \mu \mathrm{l}$ cold TCA $(10 \%, \mathrm{w} / \mathrm{v})$. After $60 \mathrm{~min}$ at room temperature, the samples were centrifuged at $12000 \mathrm{~g}$ for $10 \mathrm{~min}$. Samples $(50 \mu \mathrm{l})$ of the supernatant were assayed for radioactivity in the presence of $2 \mathrm{ml}$ Aqualyte scintillation cocktail (J. T. Baker Chemicals, the Netherlands).

Radiolabelling during heat-shock and sample preparation. Heat shock was accomplished by shifting $5 \mathrm{ml}$ of cells from $10^{\circ} \mathrm{C}$ to prewarmed test tubes $(13 \times 100 \mathrm{~mm})$ at the temperatures indicated. For the periods of protein synthesis examined, radiolabelling of cellular proteins for SDS-PAGE was done by incubating $250 \mu$ l of cells in prewarmed $1.5 \mathrm{ml}$ microcentrifuge tubes containing $30 \mu \mathrm{Ci}(1 \cdot 11 \mathrm{MBq}) \mathrm{L}-\left[{ }^{35}\right.$ S $]$ methionine (Amersham; specific activity $>37 \mathrm{TBq}^{\mathrm{mmol}}{ }^{-1}$ ). Growth was allowed to continue for $10 \mathrm{~min}$; radiolabel incorporation was then 
halted by addition of $1 \mathrm{ml}$ acetone at $-20^{\circ} \mathrm{C}$. Cells were washed twice in $1 \mathrm{ml}$ cold acetone and dried under vacuum. Dried cells were resuspended in $1 \mathrm{ml}$ of lysis buffer $(10 \mathrm{~mm}-\mathrm{Tris} / \mathrm{HCl}, \mathrm{pH} 8,2 \mathrm{mg}$ lysozyme) and incubated at $4{ }^{\circ} \mathrm{C}$ for $30 \mathrm{~min}$. Cells were washed twice with $62.5 \mathrm{mM}-\mathrm{Tris} / \mathrm{HCl}$ (pH 6.8) and resuspended in $100 \mu \mathrm{l}$ of the SDS sample buffer of Laemmli (1970). Cell walls were disrupted by sonication (Braun Labsonic; $50 \mathrm{~W}$ ) for four periods of $2 \mathrm{~min}$. Unbroken cells were removed by centrifugation at $12000 \mathrm{~g}$ for $5 \mathrm{~min}$. Samples were stored at $-80^{\circ} \mathrm{C}$.

Acid-insoluble radioactivity was determined by spotting $5 \mu \mathrm{l}$ of solubilized cell extract onto glassfibre filters (Whatman GF/C), which were then rinsed with $5 \mathrm{ml}$ cold $25 \%$ TCA and $10 \mathrm{ml}$ cold $10 \%$ TCA, followed by $10 \mathrm{ml} 96 \%(\mathrm{v} / \mathrm{v})$ ethanol. Filters were placed in $4 \mathrm{ml}$ of Aqualyte scintillation cocktail and precipitated radioactivity was determined.

$S D S-P A G E$. SDS-solubilized protein samples were heated in a boiling water-bath for $2 \mathrm{~min}$ before electrophoresis on a 1.5 -mm-thick, $12 \%(w / v)$ polyacrylamide gel overlaid with an SDS $/ 4.5 \%$ polyacrylamide stacking gel using the discontinuous buffer system of Laemmli (1970). Equal amounts of TCA-precipitable radioactivity $\left(10^{6}\right.$ c.p.m.) in equal volumes of SDS sample buffer were loaded onto each lane of a gel. Electrophoresis was done at $15^{\circ} \mathrm{C}$ and a constant $15 \mathrm{~mA}$ current per slab gel until the tracking dye entered the resolving gel, at which time the current was increased to $30 \mathrm{~mA}$. The $M_{\mathrm{r}}$ standards (Sigma) were $\alpha$-lactalbumin $\left(M_{\mathrm{r}} 14200\right)$, trypsin inhibitor (20100), trypsinogen (24000), carbonic anhydrase (29000), glyceraldehyde-3-phosphatedehydrogenase (36000), egg albumin (45000) and bovine albumin (66000). Gels were stained with $0.1 \%$ Coomassie blue R250 in $50 \%$ (v/v) methanol/7.5\% (v/v) acetic acid, and destained with $30 \%(v / v)$ ethanol $/ 10 \%(v / v)$ acetic acid. Fluorograms were made by exposing fluor-treated (Amplify; Amersham) dried gels to pre-flashed Fuji RX films.

Two-dimensional electrophoresis. Exponentially growing cells $(250 \mu \mathrm{l})$ at 10 or $32^{\circ} \mathrm{C}$ were labelled for $1 \mathrm{~h}$ with $\mathrm{L}-\mathrm{-}^{35}$ S $]$ methionine $[120 \mu \mathrm{Ci}$ $\mathrm{ml}^{-1}$ (4.44 MBq ml-1)]. Radiolabel incorporation was halted by addition of cold acetone. After washing with acetone and drying as described above, dried cells were resuspended in $50 \mu$ lof the lysis buffer of O'Farrell (1975). Isoelectric focusing (IEF) was done in $12 \times 1.5 \mathrm{~mm}$ gels following the procedure described by O'Farrell (1975). The gel mixture was $4 \%$ acrylamide, $9 \cdot 2 \mathrm{M}$-urea, $2 \%$ Nonidet $\mathrm{P} 40,5 \%$ carrier ampholytes (LKB) ampholines; 1 part pH 3.5-10, 2 parts pH 5-7). Samples $(10 \mu \mathrm{l})$ containing $10^{6}$ c.p.m. were loaded on the basic side of the gels and IEF was done for $10000 \mathrm{~V} \cdot \mathrm{h}$. Gels were then incubated for $30 \mathrm{~min}$ in the denaturing buffer of Laemmli (1970), and placed on top of a slab gel. Conventional electrophoresis in second dimension was done as described above.

Protein and DNA determination. Protein was determined by the Lowry method, with BSA as the standard. The DNA content of the cell-free extracts was estimated according to Burton (1951) using calf thymus DNA (Sigma) as the standard.

\section{Results}

\section{Effects of growth temperature on proteolytic activity in A. globiformis $S_{1} 55$}

Growth-temperature-related differences in degradation of protein fragments (cyanogen bromide peptides) in cell-free extracts of $A$. globiformis $\mathrm{S}_{1} 55$ have previously been detected (Potier et al., 1987a). Proteolysis of casein

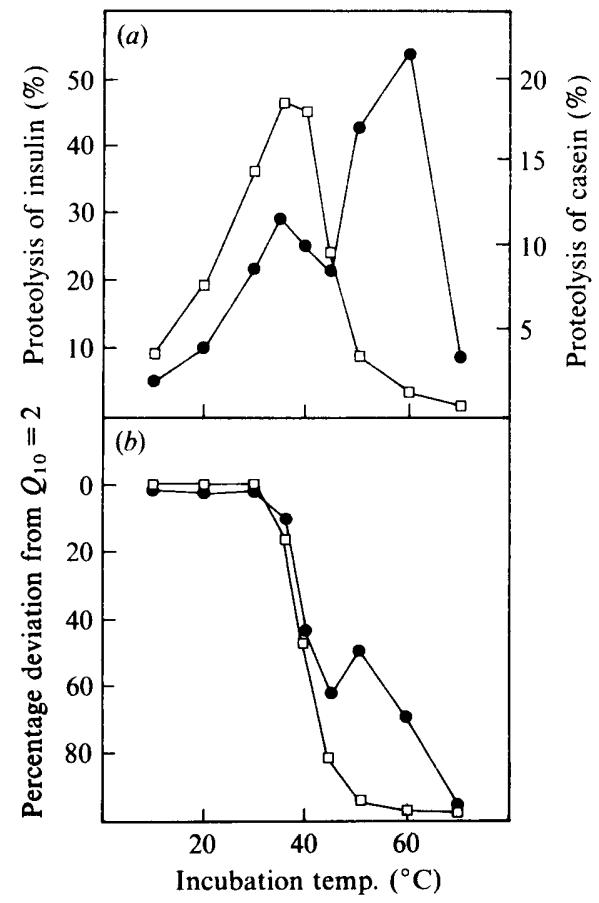

Fig. 1. (a) Effect of incubation temperature on the initial rates of proteolysis of $\left[{ }^{3} \mathrm{H}\right]$ insulin $(\square)$ and $\left[{ }^{3} \mathrm{H}\right]$ casein $(\odot)$ in cell-free extracts of A. globiformis $\mathrm{S}_{1} 55$ grown at $20^{\circ} \mathrm{C}$. Proteolysis of insulin is expressed as the percentage of $\left[{ }^{3} \mathrm{H}\right]$ insulin degraded in $10 \mathrm{~min}$ per $\mathrm{mg}$ extract protein; proteolysis of casein is expressed as the percentage of $\left[{ }^{3} \mathrm{H}\right]$ casein degraded in $30 \mathrm{~min}$ per $\mathrm{mg}$ extract protein. (b) Relationship between rates of proteolysis and incubation temperature: deviation from the $Q_{10}=2$ law. The values express the deviation between the observed and the expected proteolytic rates at each temperature based on the data obtained at $10^{\circ} \mathrm{C}$, assuming that $Q_{10}=2: 100 \%$ correspondence between the experimental and the theoretical value is equivalent to zero deviation.

\section{Table 1. Effect of growth temperature on proteolytic} activities in extracts of $A$. globiformis $S_{1} 55$

Initial rates of $\left[{ }^{3} \mathrm{H}\right]$ insulin degradation were determined after 5,10 and $15 \mathrm{~min}$, and those of $\left[{ }^{3} \mathrm{H}\right]$ casein degradation after 30,45 and $60 \mathrm{~min}$. The assay temperature was $20^{\circ} \mathrm{C}$.

\begin{tabular}{|c|c|c|}
\hline \multirow{2}{*}{$\begin{array}{l}\text { Growth } \\
\text { temperature }\end{array}$} & \multicolumn{2}{|c|}{$\begin{array}{l}\text { Initial rate of degradation } \\
\text { [ } \mu \text { g substrate hydrolysed } h^{-1} \\
(\mathrm{mg} \text { DNA in extract) })^{-1} \text { ] }\end{array}$} \\
\hline & {$\left[{ }^{3} \mathbf{H}\right]$ Insulin } & {$\left[{ }^{3} \mathbf{H}\right]$ Casein } \\
\hline $\begin{array}{l}10^{\circ} \mathrm{C} \\
20^{\circ} \mathrm{C} \\
32^{\circ} \mathrm{C}\end{array}$ & $\begin{array}{l}27 \pm 3 \\
29 \pm 2 \\
42 \pm 3\end{array}$ & $\begin{array}{l}3.8 \pm 0.4 \\
4.0 \pm 0.2 \\
7.3 \pm 0.2\end{array}$ \\
\hline
\end{tabular}

and insulin in cell-free extracts of $A$. globiformis $\mathrm{S}_{1} 55$ is effected by enzymes with differences in $\mathrm{pH}$ optima, and in metal-ion requirements and sensitivities (Potier et al., $1987 \mathrm{~b}$ ). The proteolytic activities at $20^{\circ} \mathrm{C}$ of extracts of cells grown at 10,20 and $32^{\circ} \mathrm{C}$ were compared (Table 1). Cells grown at $32{ }^{\circ} \mathrm{C}$ possessed the greatest activities 


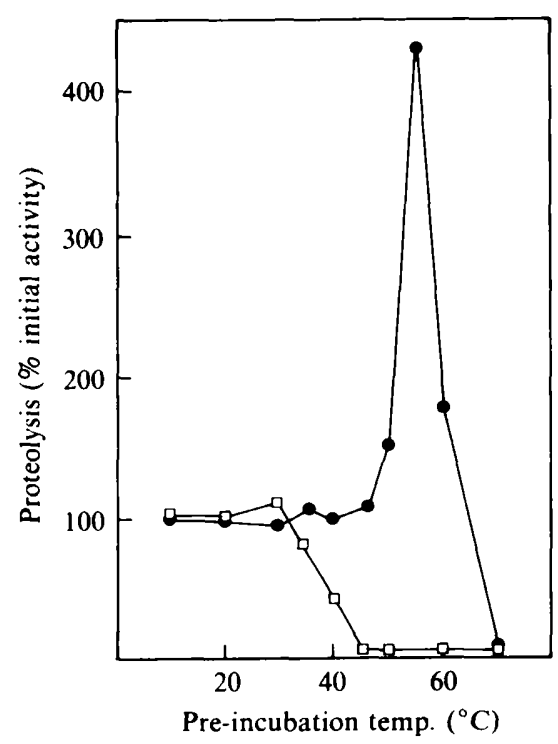

Fig. 2. Effects of pre-incubation temperature on proteolytic activities in extracts of $A$. globiformis $S_{1} 55$ grown at $20^{\circ} \mathrm{C}$. Extracts were preincubated at the indicated temperatures for $30 \mathrm{~min}$, then allowed to return to $20^{\circ} \mathrm{C}$ before addition of $\left[{ }^{3} \mathrm{H}\right]$ insulin $(\square)$ or $\left[{ }^{3} \mathrm{H}\right]$ casein $(O)$. Results are expressed as a percentage of the activities ( $\equiv 100 \%)$ detected in extracts pre-incubated at $20^{\circ} \mathrm{C}$.

towards insulin and casein and cells grown at $10^{\circ} \mathrm{C}$ the least.

\section{Heat stability of proteolytic activities in extracts of}

\section{A. globiformis $S_{1} 55$}

Using extracts obtained from cells grown at $20^{\circ} \mathrm{C}$ (optimal growth temperature), we found that the kinetics of casein and insulin degradation differed in their response to the assay temperature (Fig. $1 a$ ). $\mathrm{Up}$ to $30^{\circ} \mathrm{C}$, the two activities showed similar and expected increases in activity which appeared to obey the simple $Q_{10}=2$ law (Fig. $1 b$ ). Both activities deviated in a similar way from the theoretical values at temperatures between 30 and $40^{\circ} \mathrm{C}$. Above $40{ }^{\circ} \mathrm{C}$, proteolysis of insulin declined with increasing temperature, whereas the degradation of casein showed a second and higher peak of activity at $60^{\circ} \mathrm{C}$ (Fig. 1a). However, this stimulation was not sufficient to produce activities which approached the theoretical maximum (Fig. $1 b$ ). Similar activity profiles were obtained with extracts of cells grown at 10 and $32{ }^{\circ} \mathrm{C}$ (results not shown). The stimulation of casein degradation observed between 45 and $60^{\circ} \mathrm{C}$ was surprising. It is possible that the conformation of casein changes at the higher temperatures, thereby increasing its susceptibility to proteolysis. Additionally or alternatively, it is possible that the caseinolytic activity is itself activated above $45^{\circ} \mathrm{C}$. Evidence for this proposition was obtained by pre-incubation of cell-free extracts at

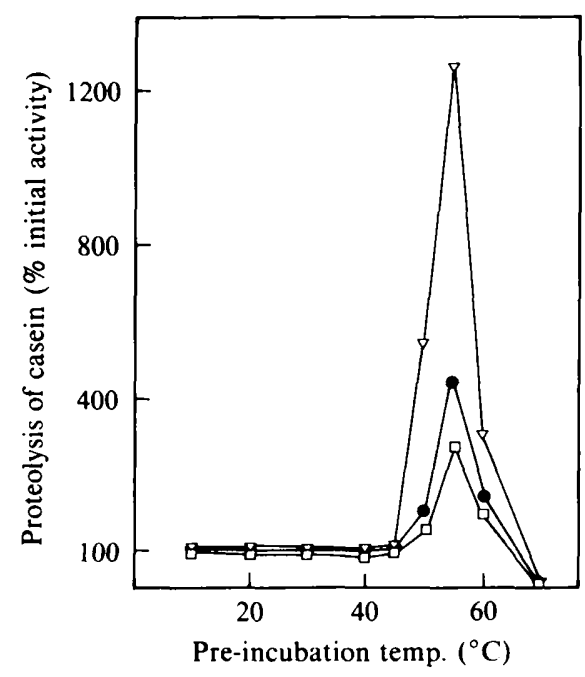

Fig. 3. Effects of pre-incubation temperature on casein-degrading activity in extracts of $A$. globiformis $S_{1} 55$. Experiments were done as in Fig. 2, except that cells were grown at $10(\square), 20(O)$ and $32{ }^{\circ} \mathrm{C}(\nabla)$.

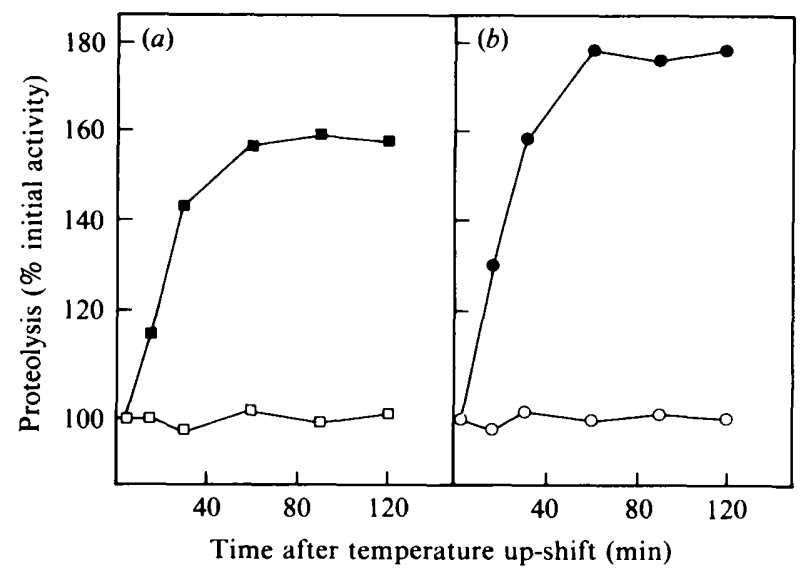

Fig. 4. Variation of insulin-degrading (a) and casein-degrading (b) activities present in extracts of $A$. globiformis $S_{1} 55$ following a temperature shift of the cells from 10 to $32^{\circ} \mathrm{C}$. Proteolytic activities were measured at $20^{\circ} \mathrm{C}$. Results are expressed as a percentage of the initial activity $(100 \%)$ measured immediately before transfer of cells to the higher temperature. Similar results were obtained in four independent experiments. $\square, 0$, Cells growin at $10^{\circ} \mathrm{C} ; \square, 0$, cells transferred to $32^{\circ} \mathrm{C}$.

temperatures up to $70^{\circ} \mathrm{C}$ for $30 \mathrm{~min}$. After cooling, the substrates were added and the proteolytic activities were assayed at $20^{\circ} \mathrm{C}$. The activity responsible for casein degradation was stimulated above $45^{\circ} \mathrm{C}$ with a maximum at $55^{\circ} \mathrm{C}$, whereas the component responsible for insulin degradation was completely inactivated by heating at $45^{\circ} \mathrm{C}$ (Fig. 2).

Growth temperature affected the relative proportion of heat-activated casein-degrading activity (Fig. 3). Cells grown at $10^{\circ} \mathrm{C}$ possessed the smallest proportion of heàtstimulated activity, which gave a 3 -fold increase in the 

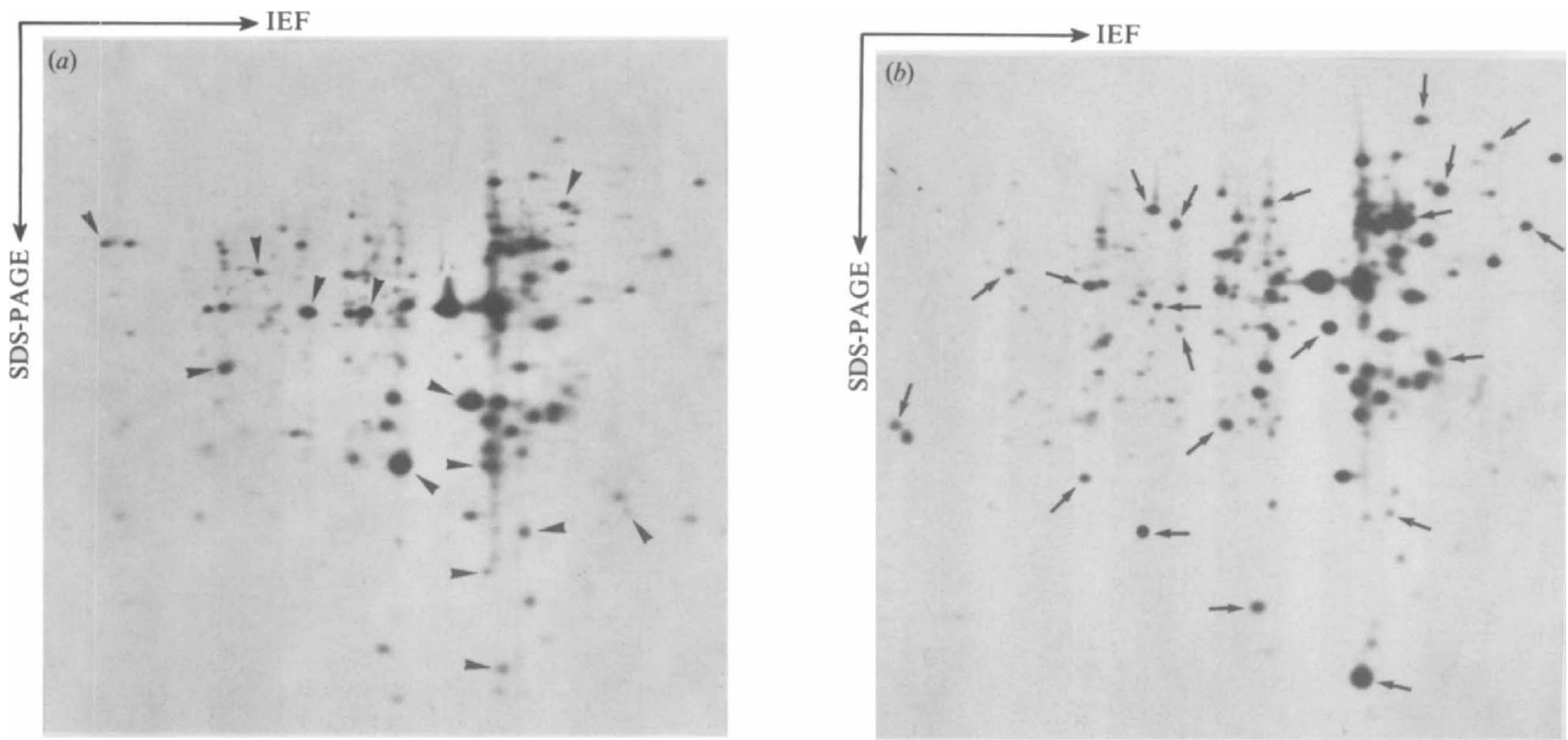

Fig. 5. Two-dimensional gel electrophoresis of polypeptides of $A$. globiformis $\mathrm{S}_{1} 55$ labelled with $\left[{ }^{3} \mathrm{H}\right]$ methionine during exponential growth at $10(a)$ or $32^{\circ} \mathrm{C}(b)$. Arrows $\left(-\right.$ and $\rightarrow$ ) indicate peptides synthesized only or preferentially at 10 and $32^{\circ} \mathrm{C}$, respectively.

rate of casein degradation, whereas a 12 -fold stimulation was observed in extracts of cells grown at $32^{\circ} \mathrm{C}$. In contrast, the heat stability pattern was identical in all extracts when insulin was used as substrate, and was similar to that reported in Fig. 2.

Changes in proteolytic activities in A. globiformis $S_{1} 55$ following temperature shifts

The results described in the previous section clearly demonstrate quantitative differences in proteolytic activities when $A$. globiformis $S_{1} 55$ is grown at low and high temperatures. We therefore investigated the response of A. globiformis $\mathrm{S}_{1} 55$ to a temperature shift from 10 to $32^{\circ} \mathrm{C}$. Parallel changes (measured at $20^{\circ} \mathrm{C}$ ) of casein and insulin degradation in cell-free extracts occurred, with maximal stimulation within $1 \mathrm{~h}$ following transfer (Fig. 4). Addition of chloramphenicol $\left(400 \mu \mathrm{g} \mathrm{ml}^{-1}\right)$ or rifampicin $\left(200 \mu \mathrm{g} \mathrm{ml}^{-1}\right)$ to the cells $15 \mathrm{~min}$ before the temperature shift prevented the increases in both proteolytic activities.

In previous studies, we demonstrated that casein hydrolysis in extracts of $A$. globiformis $\mathrm{S}_{1} 55$ was stimulated by ATP (Potier et al., 1987b,c). The caseinolytic activity in extracts of cells grown at $10^{\circ} \mathrm{C}$ was increased by up to $60 \%$ by addition of an ATPregenerating system. The temperature shift from 10 to $32^{\circ} \mathrm{C}$ resulted in increased amounts of ATP-stimulated proteolysis (up to $80 \%$ ), such that within $1 \mathrm{~h}$, the cells possessed about twice the initial ATP-stimulated activity
Table 2. Variation in proteolytic activities in extracts of A. globiformis $S_{1} 55$ after a temperature up-shift

Cells were transferred from $10^{\circ} \mathrm{C}$ to temperatures from 20 to $32^{\circ} \mathrm{C}$. Proteolytic activities of cell extracts were determined as in Table 1. Values are means of three independent experiments.

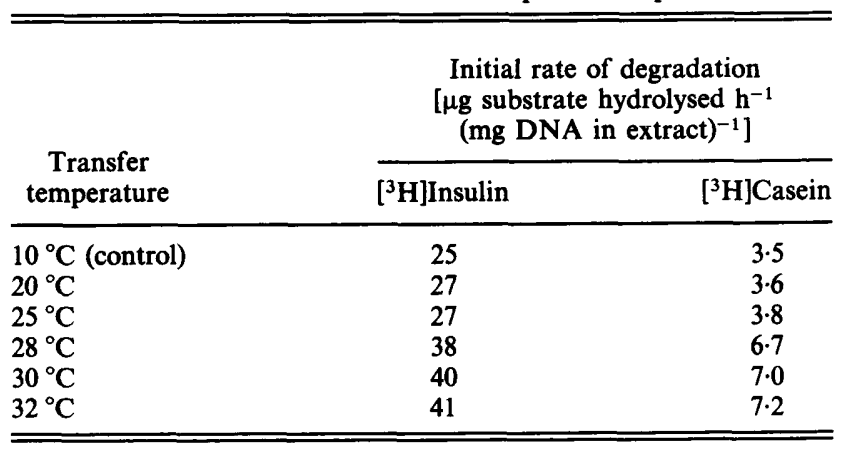

present prior to the temperature change. For the activities measured, the temperature shift increased degradation by between 60 and $100 \%$ of that originally present in cells grown at $10^{\circ} \mathrm{C}$. When the extracts were pre-incubated at $55^{\circ} \mathrm{C}$ for $30 \mathrm{~min}$, degradation of casein was increased as in Fig. 2, but the stimulation by ATP was no longer detectable (result not shown).

We also did temperature up-shift experiments designed to determine whether temperatures below the maximal permissible growth temperature could similarly trigger the changes in cell-free proteolysis measured at $20^{\circ} \mathrm{C}$. Table 2 shows that the stimulation in degradation of both insulin and casein occurred only when cells grown at $10^{\circ} \mathrm{C}$ were transferred to $28^{\circ} \mathrm{C}$ of higher. 


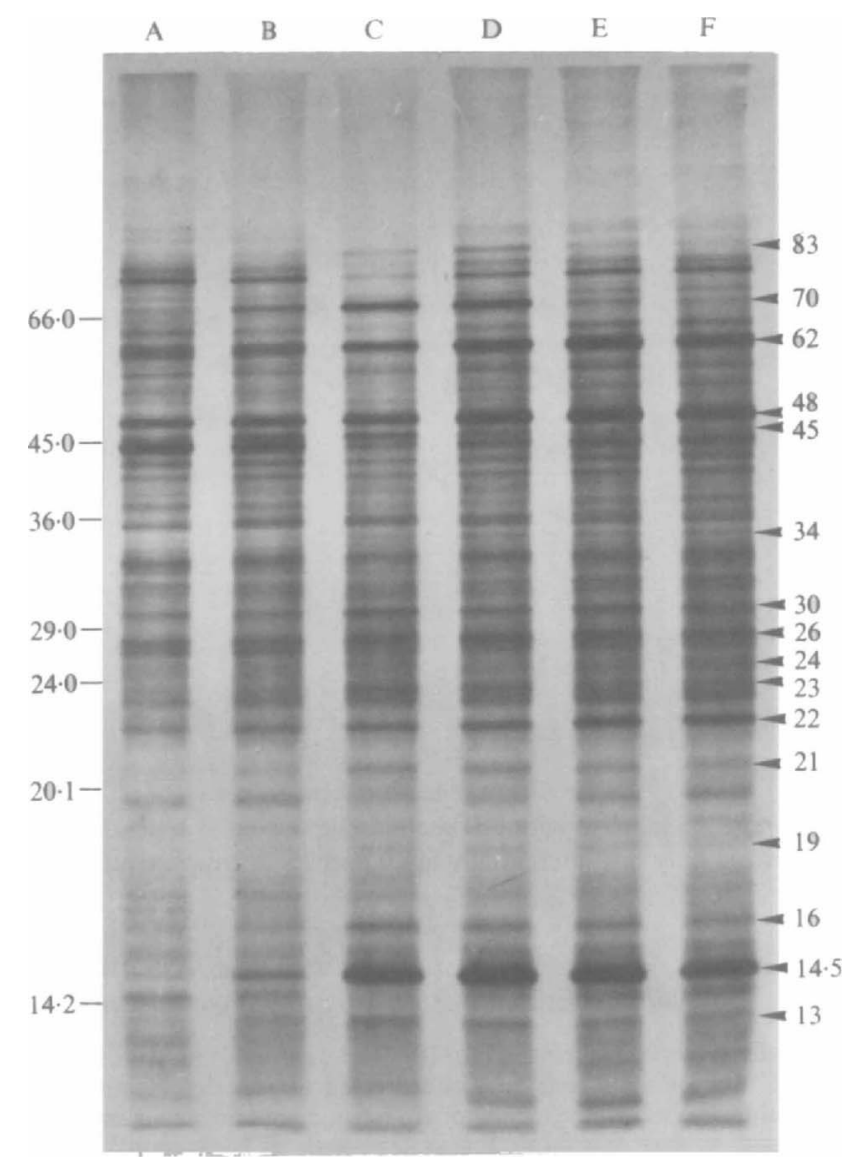

Fig. 6. Time-course of temperature-induced protein synthesis in $\boldsymbol{A}$. globiformis $\mathrm{S}_{1} 55$. Cells were shifted from 10 to $32{ }^{\circ} \mathrm{C}$ for the periods of time indicated below and labelled with $\left[{ }^{35} S\right]$ methionine for the last $10 \mathrm{~min}$ of incubation. Sample preparation and SDS-PAGE were as described in Methods. Each lane received $10^{6} \mathrm{c} . \mathrm{p} . \mathrm{m}$. of ${ }^{35} \mathrm{~S}$-labelled TCA-insoluble material. Arrows ( - ) indicate the heat shock polypeptides; pointers indicate mobilities of protein standards. Lane A, cells grown at $10^{\circ} \mathrm{C}$. Other lanes: cells shifted from 10 to $32^{\circ} \mathrm{C}$ for 15 (B), 30 (C), 60 (D), 90 (E) and $120 \mathrm{~min}(\mathrm{~F})$

Again, the increases in both activities were no longer observed in extracts obtained from cells incubated with $400 \mu \mathrm{g}$ chloramphenicol ml-1 or $200 \mu \mathrm{g}$ rifampicin ml-1 during the temperature shift. Lower temperatures did not provoke these responses; the activities in extracts of cells transferred to 20 and $25^{\circ} \mathrm{C}$ were similar to those initially present prior to transfer.

\section{Effects of temperature on protein composition of}

\section{A. globiformis $S_{1} 55$}

We were also interested to determine whether growth at low and high temperature is accompanied by differences in protein synthesis. Fig. 5 presents an analysis by twodimensional gel eleetrophoresis of the proteins present in cells labelled with ${ }^{35}$ S]methionine for $1 \mathrm{~h}$ during

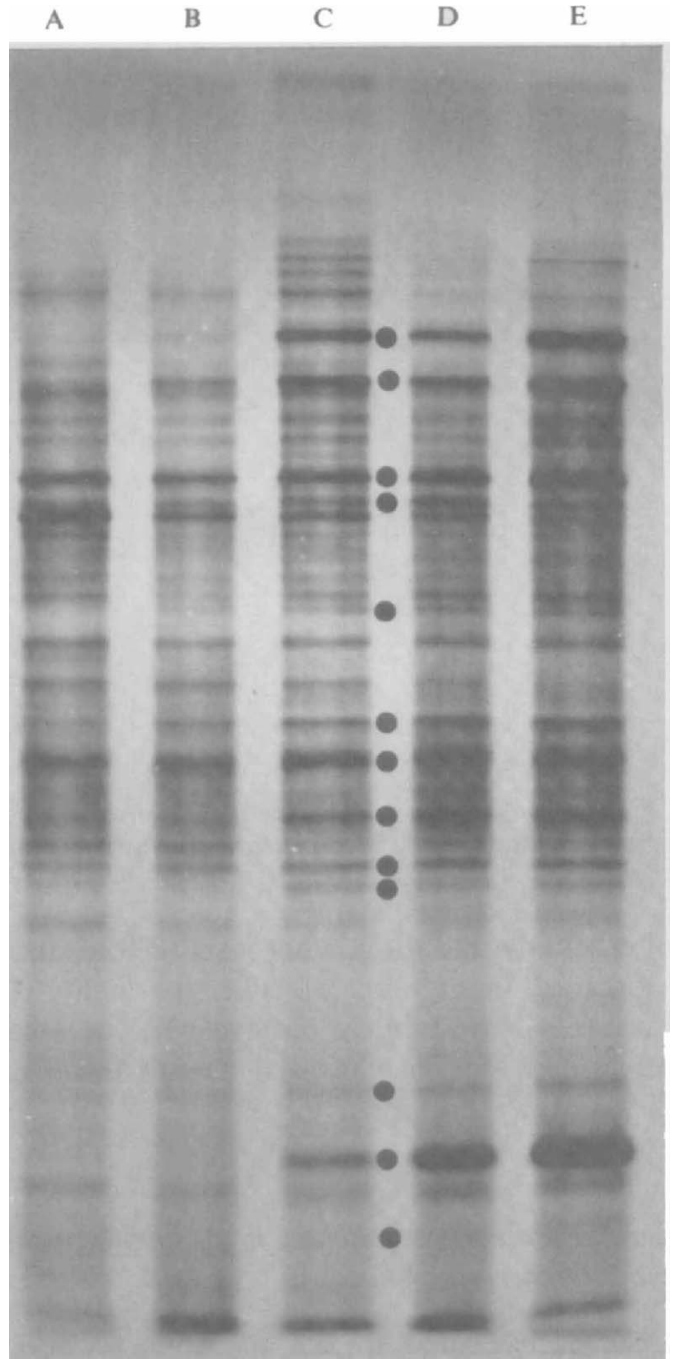

Fig. 7. Synthesis of heat shock proteins by $A$. globiformis $\mathrm{S}_{1} 55$ at various temperatures. Cells were shifted from $10^{\circ} \mathrm{C}$ to the temperatures indicated below for $1 \mathrm{~h}$. [ ${ }^{35}$ S]Methionine was added for the last $10 \mathrm{~min}$ of incubation. Cell lysis, electrophoresis and fluorography were as described in Methods. Lane A, cells grown at $10^{\circ} \mathrm{C}$. Other lanes: cells shifted for $1 \mathrm{~h}$ from $10^{\circ} \mathrm{C}$ to 20 (B), 28 (C), 30 (D) and $32^{\circ} \mathrm{C}(\mathrm{E})$. Location of heat shock proteins; from top to bottom of the gel the $M_{\mathrm{r}}$ values of the proteins are $70000,62000,48000,45000,34000,30000$, $26000,23000,22000,21500,16000,14500$ and 13500 .

exponential growth at 10 or $32^{\circ} \mathrm{C}$. At least 13 polypeptides appeared to be either exclusive or present in increased quantities following growth at $10^{\circ} \mathrm{C}$ (Fig. $5 a$ ). At $32^{\circ} \mathrm{C}$, at least 21 peptides were preferentially synthesized (Fig. $5 b$ ).

\section{Effects of temperature up-shifts on protein synthesis}

To determine if a 10 to $32{ }^{\circ} \mathrm{C}$ temperature change induces any immediate effects on protein biosynthesis, cells were radiolabelled for $10 \mathrm{~min}$ with $\left[{ }^{35} \mathrm{~S}\right]$ methionine at various 
times after such a shift. Analysis by SDS-PAGE revealed that the cells responded to the heat shock by synthesizing a set of proteins which either were not produced before the temperature shift or were produced at lower levels (Fig. 6). At least 16 polypeptides with apparent $M_{\mathrm{r}}$ values of 13000 to 83000 could be seen. Synthesis of at least eight peptides $(70,48,45,22,21,16,14.5$ and $13 \mathrm{~K})$ was stimulated in the first 15 min following the temperature change. Eight other polypeptides $(83,62,34,30,26,24$, 23 and $19 \mathrm{~K}$ ) appeared within $30 \mathrm{~min}$. Synthesis of the 83, 70 and $45 \mathrm{~K}$ species appeared to then decline after $60 \mathrm{~min}$, while others were synthesized for at least $2 \mathrm{~h}$ following transfer. Conversely, synthesis of at least three polypeptides $(42,37$ and $14 \cdot 2 \mathrm{~K})$ was transiently inhibited within $15 \mathrm{~min}$. When the cells grown at $10^{\circ} \mathrm{C}$ were transferred to $20^{\circ} \mathrm{C}$ (Fig. 7), no new proteins were detected, whereas at $28^{\circ} \mathrm{C}$ and above, synthesis of most of the new proteins occurred. It was particularly evident, however, that synthesis of the $14.5 \mathrm{~K}$ polypeptide was much greater at $32^{\circ} \mathrm{C}$ than at $28^{\circ} \mathrm{C}$.

\section{Discussion}

The results presented in this communication both extend and clarify our previous observations on the effects of temperature on intracellular protein degradation in the psychrotrophic bacterium $A$. globiformis $S_{1} 55$. We show that growth temperature determines the activity of the two proteolytic systems detected in this organism. It is noticeable that the simultaneous fall between 30 and $40^{\circ} \mathrm{C}$ in the in vitro rate of insulin and casein degradation occurred at temperatures that also limit growth of $\boldsymbol{A}$. globiformis $\mathrm{S}_{1} 55$. It is now well-established that intracellular protein breakdown is a fundamental process that participates in a number of important physiological functions in cells, including protein maturation and secretion (Davis \& Tal, 1980), regulation of the level of intracellular proteins (Goldberg \& St John, 1976; Mosteller et al., 1980), elimination of abnormal peptides (Goff \& Goldberg, 1985; Goldberg, 1972) and provision of amino acids for the synthesis of proteins required for adaptation (Mandelstam, 1963). Therefore the diminution above $30^{\circ} \mathrm{C}$ of the efficiency of the proteolytic system present in $A$. globiformis $\mathrm{S}_{1} 55$ could contribute to the cessation of growth at these temperatures.

The heat-induced activation of casein degradation is intriguing and has yet to be explored. Unfolding of one or more of the enzymes involved to widen its specificity, binding of activating ligands or heat-denatured proteins, or the denaturation or dissociation of an inhibitor are areas worthy of consideration. Our previous findings, where we employed a heterogeneous polypeptide substrate (cyanogen bromide peptides), also indicated that growth temperature has major effects on the total proteolytic activity present in $A$. globiformis $S_{1} 55$, and on the proportion which is activated by heat (Potier $e$ t al., 1987a). The physiological function of this apparently latent proteolytic activity is also unknown. Circumstances which require rapid increases in proteolytic activity, in the absence of protein synthesis, might be considered likely. This may be especially important when one considers the natural environment (cold and nutritionally poor) of $A$. globiformis $\mathrm{S}_{1} 55$, where rates of protein synthesis might be expected to be slow, but when a rapid increase in proteolytic activity might be necessary to cope with sudden changes in the environment.

It is also striking that the proteolytic activity of cells grown at $32{ }^{\circ} \mathrm{C}$ is greater than that of cells grow at 10 or $20^{\circ} \mathrm{C}$. Such an increase might be expected because the protein content of the cells grown at this temperature is up to $45 \%$ greater than that of cells grown at 10 or $20^{\circ} \mathrm{C}$ (protein:DNA ratios cells grown at for 10,20 and $32^{\circ} \mathrm{C}$ were $8 \cdot 7 \pm 0 \cdot 2,8 \cdot 5 \pm 0 \cdot 4$, and $11 \cdot 4 \pm 0 \cdot 3$, respectively). Therefore, one might expect the cells to produce more enzymes to deal with the increased amount of substrate should the necessity arise. In addition, cells growing close to their maximal permitted temperature are reported to produce continuously some heat shock proteins, some of which are proteases (Goff et al., 1984; Goff \& Goldberg, 1987) or enhance protein degradation (Straus et al., 1988). Therefore, it is likely that $A$. globiformis $\mathrm{S}_{1} 55$, when cultured at $32^{\circ} \mathrm{C}$, similarly synthesizes increased amounts of heat shock proteins which could contribute to the temperature-dependent increases in proteolytic activities that we detected. Furthermore, we speculatively suggest that the increased level of casein-degrading activity measured at higher temperatures may be a particular example of such a stress-related enzyme.

Of special interest is the ATP-stimulated caseinolytic activity, which increases proportionately more than the ATP-independent enzymes following the 10 to $32^{\circ} \mathrm{C}$ temperature shift. In E. coli, protease La is an ATPstimulated protease and also heat shock protein (Chung \& Goldberg, 1981; Phillips et al., 1984). It is possible, therefore that one or more analogous enzymes exist in $A$. globiformis $\mathrm{S}_{1} 55$, and that such enzymes are responsible for the increase in caseinolytic activity at higher temperatures. After heat-activation of the caseinolytic activity, the ATP stimulation was no longer detected, either because heat-provoked effects eliminated the ATP-mediated response, or the ATP effects became masked by the elevated activity.

The temperature-shift experiments also revealed rapid changes in protein synthesis in $A$. globiformis $S_{1} 55$. It may be coincidental that the changes in protein synthesis 
(Fig. 6) and proteolytic activities (Fig. 4) were similarly rapid, as were the temperatures which elicited these responses (Table 2, Fig. 7). It is tempting to suggest that some of the proteins specifically synthesized following a temperature shift may indeed represent proteolytic enzymes and/or activators. Furthermore, the increase in protease activity detected when the temperature of the culture was raised is not likely to result from heatactivation of the pre-existing caseinolytic activity, because the latter phenomenon was only observed above $45^{\circ} \mathrm{C}$ in the in vitro studies.

Growth of $A$. globiformis $\mathrm{S}_{1} 55$ at low and high temperatures was associated with the appearance of a number of unique polypeptide species particular to 10 or $32^{\circ} \mathrm{C}$. While the functions of these peptides are unknown, some might be concerned with proteolytic activity and its regulation as discussed above. It is possible that some of these proteins are necessary for growth at these temperatures, thereby reflecting adaptive responses of the cells. Alternatively, the appearance of temperature-specific proteins may be secondary responses to other temperature-regulated activities which alter the metabolism or expression of these polypeptides. The fact that protease activities differ at 10 and $32{ }^{\circ} \mathrm{C}$ increases the likelihood that changes in protein processing might occur.

McCallum et al. (1986) demonstrated that increases in culture temperature of the strictly psychrophilic Arctic bacterium Res-10 and the psychrotroph Bacillus psychrophilus induce the synthesis of a number of proteins (heat shock proteins) with $M_{\mathrm{r}}$ values similar to those of proteins detected in $A$. globiformis $\mathrm{S}_{1} 55$, and which are also detected in $E$. coli at higher temperatures (Neidhardt \& VanBogelen, 1987). Hence we suggest that expression of the heat shock proteins is not regulated by the absolute temperature. The important event in the induction of the heat shock genes might involve the effects of heat on those controlling elements which determine the activation of the relevant regulon(s). Temperatures considered to be extreme for one organism might be tolerable by another. In fact, the same biochemical event may occur at a relatively high temperature for a mesophile, and at a much lower temperature for a psychrophile. The molecular bases of the relevant protein thermocouples would make an interesting evolutionary study: eventually the application of protein engineering techniques might permit the design of a range of molecules, each of which may respond to a specific temperature.

Finally, psychrophiles growing at low temperatures and possessing low proteolytic activities might be considered suitable tools for the production of commercially and medically useful molecules which are very susceptible to proteolysis at higher temperatures in other organisms. For example, interferon $\alpha-2$ is rapidly degraded at $37^{\circ} \mathrm{C}$ in E. coli and Methylophilus methylotrophus, but is stable in both organisms at $29^{\circ} \mathrm{C}$ and below (Chesshyre \& Hipkiss, 1989). Other polypeptides of interest might undergo similar stabilization, but at much lower temperatures.

\section{References}

Anathan, J., Goldberg, A. L. \& Voellmy, R. (1986). Abnormal proteins serve as eukaryotic stress signal and trigger the activation of heat shock genes. Science 232, 522-524.

Burton, J. (1951). A study of the conditions and mechanisms of the diphenylamine reaction of the colorimetric estimation of deoxyribonucleic acid. Biochemical Journal 162, 315-323.

Chesshyre, J. A. \& Hipkiss, A. R. (1089). Low temperature stabilizes interferon $\alpha-2$ against proteolysis in Methylophilus methylotrophus and Escherichia coli. Applied Microbiology and Biotechnology 31, 158162.

Chung, C. H. \& Goldberg, A. L (1981). The product of the lon (capR) gene in Escherichia coli is the ATP-dependente protease La. Proceedings of the National Academy of Sciences of the United States of America 78, 4931-4935.

CraIG, E. A. (1985). The heat shock response. Critical Reviews in Biochemistry 18, 239-280.

DAVIS, B. D. \& TAL, P. C. (1980). The mechanism of protein secretion across membranes. Nature, London 283, 433-438.

Goff, S. A., Casson, L. P. \& GoldberG, A. L. (1984). The heat shock regulatory gene $h t p R$ influences rates of protein degradation and expression of the lon gene in Escherichia coli. Proceedings of the National Academy of Sciences of the United States of America 81, $6647-6651$

GofF, S. A. \& Goldberg, A. L. (1985). Production of abnormal proteins in Escherichia coli stimulates transcription of lon and other heat shock genes. Cell 41, 587-595.

GoFF, S. A. \& Goldberg, A. L. (1987). An increased content of protease La, the lon gene product, increases protein degradation and blocks growth in Escherichia coli. Journal of Biological Chemistry 262, 4508-4515.

GoldBERG, A. L. (1972). Degradation of abnormal proteins in Escherichia coli. Proceedings of the National Academy of Sciences of the United States of America 69, 422-426.

GoldberG, A. L. \& ST JoHN, A. C. (1976). Intracellular protein degradation in mammalian and bacterial cells (2). Annual Review of Biochemistry 45, 747-803.

Gounot, A. M. (1976). Effects of temperature on the growth of the psychrophilic bacteria from glaciers. Canadian Journal of Microbiology 22, 357-362.

IChihara, S., Beppu, N. \& Mizushima, S. (1984). Protease IV, a cytoplasmic protein of Escherichia coli, has signal peptide peptidase activity. Journal of Biological Chemistry 259, 9853-9857.

KelLy, P. M. \& SCHLesinger, M. J. (1978). The effect of amino acid analogues and heat shock on gene expression in chicken embryo fibroblast. Cell 15, 1277-1286.

LAEMMLI, U. K. (1970). Cleavage of structural proteins during the assembly of the head of bacteriophage T4. Nature, London 227, 680685.

McCallum, K. L., Heikkila, J. J. \& InNiss, W. E. (1986). Temperature-dependent pattern of heat-shock protein synthesis in psychrophilic and psychrotrophic microorganisms. Canadian Journal of Microbiology 32, 516-521.

Mandelstam, J. (1963). Protein turnover and its function in the economy of the cell. Annals of the New York Academy of Sciences 102, $621-636$.

MorITA, R. Y. (1975). Psychrophilic bacteria. Bacteriological Reviews 39, $144-167$.

Mosteller, R. D., Goldstein, R. V. \& Nishimoto, K. R. (1980). Metabolism of individual proteins in exponentially growing Escherichia coli. Journal of Biological Chemistry 255, 2524-2532. 
Munro, S. \& Pelham, H. (1985). What turns on heat shock genes? Nature, London 317, 477-478.

Neidhardt, F. C., VanBogelen, R. A. \& Vaughn, V. (1984). The genetics and regulation of heat-shock proteins. Annual Review of Genetics 18, 295-329.

NeIDHARdT, F. C. \& VANBogrlen, R. A. (1987). Heat shock response. In Escherichia coli and Salmonella typhimurium: Cellular and Molecular Biology, pp. 1334-1345. Edited by F. C. Neidhardt, J. L. Ingraham, K. B. Low, B. Magasanik, M. Schaechter \& H. E. Umbarger. Washington, DC: American Society for Microbiology.

O'FARRELL, P. H. (1975). High resolution two-dimensional electrophoresis of proteins. Journal of Biological Chemistry 250, 4007-4021.

Phillips, T. A., VanBogelen, R. A. \& Neidhardt, F. C. (1984). lon gene product of Escherichia coli is a heat-shock protein. Journal of Bacteriology 159, 283-287.

Potier, P., Hipkiss, A. R. \& Kushner, D. J. (1985). Protein turnover in a psychrotrophic bacterium. Archives of Microbiology 142, 28-33.

Potier, P., Drevet, P., Gounot, A. M. \& Hipkiss, A. R. (1987a). Protein turnover in a psychrotrophic bacterium: proteolytic activity in extracts of cells grown at different temperatures. FEMS Microbiology Letters 44, 267-271.

Potier, P., Drevet, P., Gounot, A. M. \& Hipkiss, A. R. (1987b) ATP-dependent and -independent protein degradation in extracts of the psychrotophic bacterium Arthrobacter sp. $\mathrm{S}_{1} 55$. Journal of General Microbiology 133, 2797-2806.

Potier, P., Drevet, P., Gounot, A. M. \& HiPkiss, A. R. (1987c). Proteolysis in cell-free extracts of the psychrophilic (cold-loving) bacterium Arthrobacter sp. $S_{1} 55$ : effects of growth temperature and ATP. Biochemical Society Transactions 15, 968-969.

RiCE, R. H. \& MEANs, G. E. (1970). Radioactive labelling of proteins in vitro. Journal of Biological Chemistry 246, 831-832.

Straus, D. B., WalTER, W. A. \& Gross, C. A. (1988). Escherichia coli heat shock gene mutants are defective in proteolysis. Genes and Development 2, 1851-1858.

Yamamori, T., ITo, K., Nakamura, Y. \& Yura, T. (1978). Transient regulation of protein synthesis in Escherichia coli upon shift-up of growth temperature. Journal of Bacteriology 134, 1133-1140. 